Eur. J. Clin. Chem. Clin. Biochem.

Vol. 31, 1993, pp. 153-157

(C) 1993 Walter de Gruyter \& Co. Berlin - New York

\title{
Semiquantitative Assay of Human Chorionic Gonadotropin by a Simple and Fast Immunofiltration Technique
}

\author{
By $A$. Rapak and $A$. Szew'czuk \\ Laboratorium Biochemii, Instytut Immunologii i Terapii Doświadczalnej PAN, Wroclaw, Polska
}

(Received April 27/November 26, 1992)

Summary: An immunofiltration technique for the semiquantitative assay of human chorionic gonadotropin (hCG) was applied in two versions, using different antibodies. One anti- $\beta$ hCG subunit was immobilized on a glass microfibre disc in the form of six radially located bars, and the dry disc was placed on a waterabsorbing material in a plastic device. A second antibody labelled with horse radish peroxidase conjugate was used in solution. For the colour reaction a solution with tetramethylbenzidine and hydrogen peroxide was used. The number of blue bars appearing on the test disc depended on concentration range of human chorionic gonadotropin. The technique with the monoclonal antibodies, anti- $\beta$ hCG and anti- $\alpha$ hCG-horse radish peroxidase conjugate, was specific for intact human chorionic gonadotropin, while the technique with the rabbit antibodies, raised against synthetic fragment 122-145- $\beta \mathrm{hCG}$ and $\beta \mathrm{hCG}$-horse radish peroxidase, was useful for both intact human chorionic gonadotropin and its $\beta$-chain. Cross reactions with human lutropin and thyrotropin were negligible. Haemoglobin, urea and various tested drugs did not affect the assay. In the assay of human chorionic gonadotropin in the urine of pregnant women and in sera of patients with trophoblastic diseases, the results from the immunofiltration technique were in accordance with data obtained by classical ELISA and by two commercial kits.

\section{Introduction}

Human chorionic gonadotropin (hCG) is synthesized by syncytiotrophoblastic cells of the placenta and by trophoblastic cells of some cancers. Therefore, the detection of human chorionic gonadotropin in urine or serum is useful in obstetric and oncological diagnosis $(1,2)$. During the last decade, simple and fast techniques, like immunometric multilayer (3), dipstick (4), immunoconcentration $(5,6)$, one-step chromatography (7), enzyme channelling (8) and radial partition immunoassay (9), have been described for the detection and semiquantitative assay of human chorionic gonadotropin.

The immunofiltration technique presented in this paper is fast, sensitive and simple, and can be performed by an unskilled person even under non-laboratory conditions.

\section{Materials and Methods}

\section{Hormones}

Purified human chorionic gonadotropin, isolated from a commercial hormone preparation (3000-4000 IU/mg, Calbiochem) by chromatography on DEAE- and CM-cellulose, was dissociated in $8 \mathrm{~mol} / \mathrm{l}$ urea, and the $\alpha$ - and $\beta$-subunits were separated on DEAE-Sephadex column (10). The 3rd International Standard for chorionic gonadotropin (code No. 75/537) was from the International Biological Standards Board (Great Britain). Human lutropin and thyrotropin were purchased from Calbiochem.

\footnotetext{
Antibodies

Monoclonal antibodies "MoAb anti- $\beta$ hCG $\left(\mathrm{IgG}_{1}\right)$ No. 9" and "MoAb anti- $\alpha$ hCG $\left(\operatorname{IgG}_{2 a}\right)$ No. 99" were produced according to the general procedure of Köhler \& Milstein (11), and isolated from mouse ascites fluid on a protein A-Sepharose column (12). Their affinity constants for the $\beta$ - and the $\alpha$-chain of human chorionic gonadotropin are $1.16 \times 10^{10}$ and $4.28 \times 10^{9}$, and their cross reactions with human lutropin are 0.3 and $100 \%$, respectively (13).
} 
Rabbit antisera were obtained by immunization of rabbits with $\beta h C G$ or synthetic fragment 122-145- $\beta$ hCG conjugated to thyreoglobulin. Rabbit antibodies were isolated from antisera by immunoaffinity chromatography as described for goat antibodies (14).

Antibodies were conjugated to horse radish peroxidase') (Type VI, Sigma) by a modified periodate procedure (15). Antibodies and human chorionic gonadotropin were radioiodinated by a modified chloramine method (16) using $18.5 \mathrm{MBq}$ of Na ${ }^{125} \mathrm{I}$ per $50 \mu \mathrm{g}$ antibody and per $5 \mu \mathrm{g}$ human chorionic gonadotropin. Specific radioactivities of iodinated proteins isolated on Sephadex G-25 column were $0.37 \mathrm{MBq} / \mu \mathrm{g}$ antibody and $1.48 \mathrm{MBq} /$ $\mu \mathrm{g}$ human chorionic gonadotropin.

\section{Preparation of the immunofilter}

Six solutions containing $1,0.08,0.02,0.01,0.005$ and 0.0025 $\mathrm{g} / \mathrm{l}$ of MoAb anti- $\beta$ hCG or anti-122-145- $\beta$ hCG in $0.1 \mathrm{~mol} / \mathrm{l}$ Tris buffer, $\mathrm{pH} 8.3$, and rabbit $\mathrm{IgG}(1 \mathrm{~g} / \mathrm{l})$ were used for drawing six radially located bars $(4 \mathrm{~mm}$ length and $1 \mathrm{~mm}$ wide) on a glass microfibre sheet (Whatman AH 934) with a plotter-computer system. Human chorionic gonadotropin/antibody complex $(0.01 / 0.1: \mathrm{g} / \mathrm{l})$ was also immobilized as a control bar. The sheet was dried, and the immunofilter disc (18 $\mathrm{mm}$ diameter) was cut out and placed on water-absorbing material in a plastic device. The immunofilter disc in the device was covered with dry percolating filter Whatman AH 934, soaked with $10 \mathrm{~g} / \mathrm{l}$ casein in $0.5 \mathrm{~mol} / \mathrm{l}$ Tris buffer, $\mathrm{pH} 8.3$ and dried. The device with the two filters was stored dry at $4-8^{\circ} \mathrm{C}$.

Assay of human chorionic gonadotropin by the immunofiltration technique

Urine or serum $(0.2 \mathrm{ml})$ was pipetted onto the percolating filter and allowed to drain $(1 \mathrm{~min})$. A drop $(0.2 \mathrm{ml})$ of a solution of a proper antibody-horse-radish peroxidase conjugate $(6 \mathrm{mg} / \mathrm{l})$ in $10 \mathrm{~g} / \mathrm{l}$ casein, $0.05 \mathrm{~mol} / \mathrm{l}$ buffer, $\mathrm{pH} .7 .6$, stabilized with 0.5 $\mathrm{g} / \mathrm{l}$ thimerosal and $0.2 \mathrm{~g} / \mathrm{l}$ gentamycin (reagent $\mathrm{A}$ ), was then placed on the percolating filter. After draining $(2 \mathrm{~min})$ the percolating filter was removed and the immunofilter was washed twice with $0.15 \mathrm{ml}$ of a solution of $0.1 \mathrm{~g} / 1$ Triton QS 44 in $0.5 \mathrm{~mol} / \mathrm{l} \mathrm{NaCl}, 10 \mathrm{mmol} / \mathrm{l}$ buffer, $\mathrm{pH} 7.6$ (reagent B). Finally $0.15 \mathrm{ml}$ of a solution containing $1 \mathrm{mmol} / \mathrm{l} 3,3^{\prime} 5,5^{\prime}-$ tetramethylbenzidine (Serva), $3 \mathrm{mmol} / \mathrm{l}$ hydrogen peroxide, 0.1

1) Enzyme

Peroxidase EC 1.11.1.7 mol/l citric-phosphate buffer, $\mathrm{pH} 5.0$, and $230 \mathrm{~g} / \mathrm{l}$ isopropanol (reagent $C$ ) was placed on the immunofilter. The colour reaction was allowed to proceed for $3 \mathrm{~min}$, then $0.15 \mathrm{ml} 10 \mathrm{~g} / \mathrm{l}$ sodium fluoride (reagent D) was placed on the immunofilter. The number of blue bars on the immunofilter shows the concentration range of human chorionic gonadotropin in the assayed sample. If the human chorionic gonadotropin concentration was $\geqslant 1300 \mathrm{IU} / \mathrm{l}$, the urine or serum was diluted with phosphatebuffered saline.

ELISA determination of human chorionic gonadotropin in pregnancy urine

Wells in microtitre plates (type F, Nunc) were coated with purified antibody $(5 \mathrm{~g} / \mathrm{l})$ in phosphate buffered saline for $1 \mathrm{~h}$ at room temperature. After blocking with $2 \mathrm{~g} / \mathrm{l}$ casein in phosphate buffered saline for $30 \mathrm{~min}$ and washing twice with caseinphosphate buffered saline solution the wells were incubated for $1 \mathrm{~h}$ with urine sample $(0.1 \mathrm{ml} /$ well) diluted with casein-phosphate buffered saline. The wells were washed twice with caseinphosphate buffered saline and incubated for $1 \mathrm{~h}$ with antibodyhorse radish peroxidase conjugate $(0.5 \mathrm{mg} / \mathrm{l})$ in casein-phosphate buffered saline. Then the wells were washed and incubated with $5 \mathrm{mmol} / \mathrm{l} o$-phenylenediamine and $6 \mathrm{mmol} / \mathrm{l}$ hydrogen peroxide in $0.1 \mathrm{~mol} / 1$ citrate buffer, $\mathrm{pH} 5.0,(0.1 \mathrm{ml} /$ well $)$ for $10 \mathrm{~min}$. The colour reaction was stopped with $2 \mathrm{~mol} / 1 \mathrm{H}_{2} \mathrm{SO}_{4}$ $(0.1 \mathrm{ml} /$ well) and absorbances were measured in an EIA Reader (Dynatech) at $490 \mathrm{~nm}$.

\section{Other assays}

Human chorionic gonadotropin in sera of patients suffering from trophoblastic cancers was assayed using ABBOTT $\beta$-hCG 15/1.5 Test (Abbott Lab) and Enzymun Test HCG (No. 855332, Boehringer Mannheim) according to the manufacturer's instructions.

\section{Results}

Adsorption of the antibodies onto glass fibre sheet

As observed in our laboratory, mouse and rabbit immunoglobulins adsorb onto glass microfibre sheets. This phenomenon was investigated using solutions

Tab. 1. Effect of washing on monoclonal and polyclonal antibodies (MoAbs and Abs) adsorbed to glass microfibre sheet (Whatman AH 934).

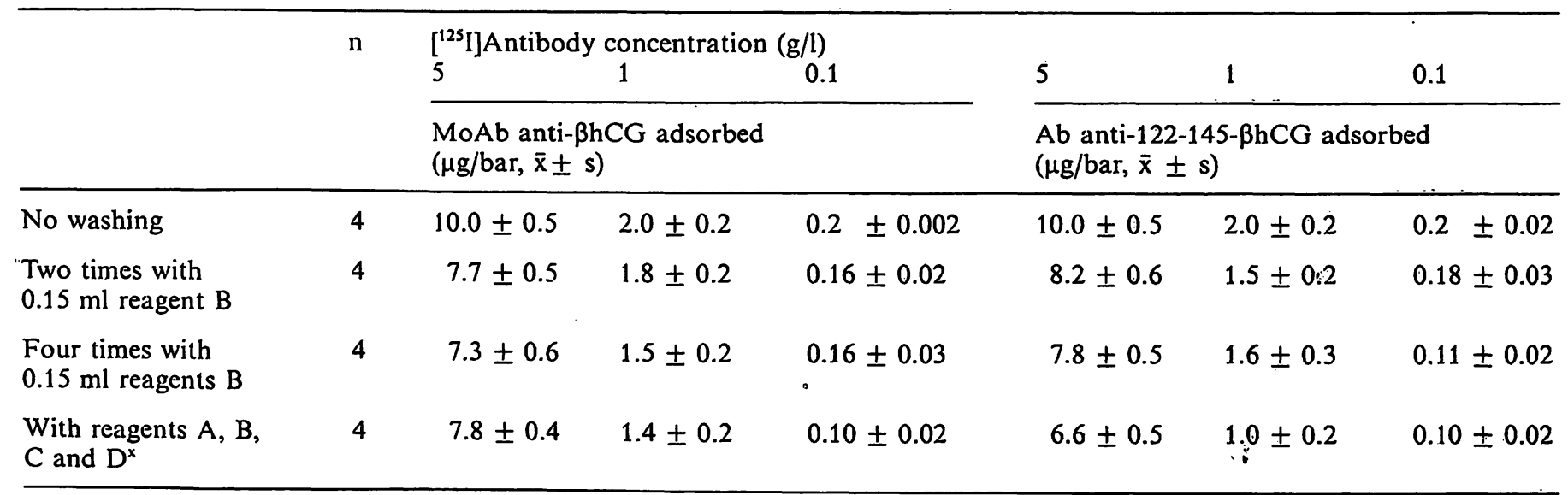

After washing, bars were cut out and their radioactivity measured.

${ }^{x}$ as described in Methods. 
Tab. 2. Binding of ${ }^{125}$ I-labelled human chorionic gonadotropin to MoAb anti- $\beta$ hCG bars on immunofilters

\begin{tabular}{|c|c|c|c|c|}
\hline \multirow{3}{*}{$\begin{array}{l}\text { MoAb anti- } \beta \text { hCG } \\
\text { on immunofilter } \\
(\mu \mathrm{g} / \mathrm{bar})\end{array}$} & \multicolumn{4}{|c|}{${ }^{125}$ I-Labelled human chorionic gonadotropin (ng for immunofilter) } \\
\hline & 170 & 42 & 8 & 0.8 \\
\hline & \multicolumn{4}{|c|}{ Human chorionic gonadotropin bound (ng/bar) } \\
\hline 2 & $1.0 \pm 0.06$ & $1.0 \pm 0.07$ & $0.19 \pm 0.03$ & $0.055 \pm 0.010$ \\
\hline 0.16 & $0.26 \pm 0.018$ & $0.20 \pm 0.02$ & $0.056 \pm 0.013$ & - \\
\hline 0.04 & $0.10 \pm 0.012$ & $0.088 \pm 0.012$ & $0.049 \pm 0.013$ & - \\
\hline 0.02 & $0.072 \pm 0.011$ & $0.06 \pm 0.010$ & $0.046 \pm 0.012$ & - \\
\hline
\end{tabular}

Preparation of immunofilters and determination of hormone binding are described under Methods.

with monoclonal antibody and antibody, both labelled with ${ }^{125}$ I for drawing bars on the glass sheets (Whatman AH 934). The dry immunofilters obtained were washed as described for immunofiltration technique and the remaining radioactivity of bars was measured. Results are presented in table 1 . Only $25-$ $50 \%$ of each antibody was eluted from the immunofilter either with reagent $B$ or with all four reagents used in the immunofiltration technique.

When rabbit $\operatorname{IgG}(1 \mathrm{~g} / \mathrm{l})$ was added to the solution containing ${ }^{125}$ I-labelled antibody, there was increase in the quantity of antibody adsorbed onto the glass sheet. The amount of human chorionic gonadotropin binding to antibody bars depends on the antibody concentration in the bars, e.g. a maximum of $1 \mathrm{ng}$ ${ }^{125}$ I-labelled human chorionic gonadotropin was bound to one bar containing $2 \mu \mathrm{g}$ of MoAb antiBhCG (tab. 2) or Ab anti-122-145- $\beta$ hCG.

\section{Immunofiltration technique} with monoclonal antibodies

The number of blue bars appearing on the immunofilter with MoAb- $\beta$ hCG bars using MoAb- $\alpha$ hCGhorse radish peroxidase depends on the concentration of human chorionic gonadotropin (fig. 1). By using 3rd International Standard for human chorionic gonadotropin, it was possible to determine human chorionic gonadotropin in the range $20 \mathrm{IU} / 1$ to $1300 \mathrm{IU} / \mathrm{l}$ (tab. 3). The range of assayed human chorionic gonadotropin concentration can be increased by dilution of investigated samples either with reagent $A$ or with phosphate buffered saline. Also, dilution of samples with serum or urine from healthy and non-pregnant persons did not affect assays with immunofiltration technique. Addition of known amounts of $300 \mathrm{IU} / 1$ and $800 \mathrm{IU} / \mathrm{l}(\mathrm{n}=6)$ to urine and serum samples gave complete analytical recoveries. A high-dose hook effect was not observed, even with $10^{6} \mathrm{IU} / \mathrm{l}$.

Using the two monoclonal antibodies, only intact human chorionic gonadotropin could be assayed by immunofiltration technique. The technique was neg-

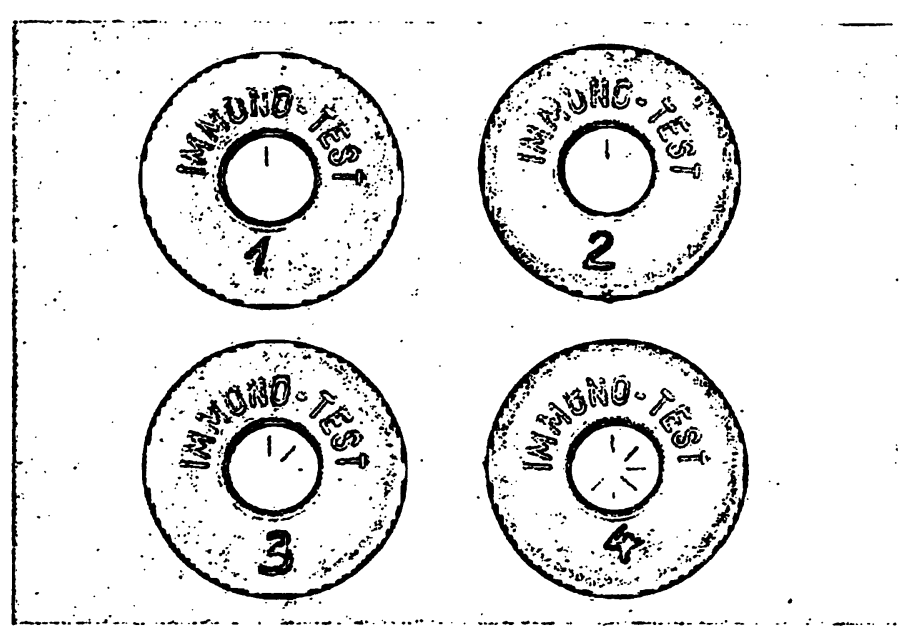

Fig. 1. Immunofilter discs in plastic devices after assay of human chorionic gonadotropin (3rd International Standard for human chorionic gonadotropin 75/537) by immunofiltration technique. 1, $0.0 \mathrm{IU} / \mathrm{l} ; 2,50 \mathrm{IU} / \mathrm{l} ; 3$, $500 \mathrm{IU} / 1 ; 4,2000 \mathrm{IU} / \mathrm{l}$. Standard was dissolved in reagent $A$ and assays were performed with two monoclonal antibodies as described in Methods.

Tab. 3. Calibration of immunofiltration technique with standard hCG (3rd International Standard for human chorionic gonadotropin $75 / 537$ )

\begin{tabular}{lc}
\hline $\begin{array}{l}\text { Number of } \\
\text { blue bars }\end{array}$ & $\begin{array}{l}\text { Human chorionic } \\
\text { gonadotropin } \\
(\text { IU } / 1)^{x}, \text { range }\end{array}$ \\
\hline 1 & $\leqslant 20$ \\
2 & $20-60$ \\
3 & $60-200$ \\
4 & $200-500$ \\
5 & $500-850$ \\
6 & $850-1300$ \\
7 & $\geqslant 1300$ \\
\hline
\end{tabular}

MoAb anti- $\beta$ hCG immobilized on test filters and MoAb anti$\alpha$ hCG-horse radish peroxidase conjugate were used as described in Methods.

$\times$ Diluted in reagent $A$.

ative with human lutropin and human thyrotropin $(1000 \mathrm{IU} / \mathrm{l})$ and with serum and urine from healthy men and non-pregnant or post-menopausal women.

Human chorionic gonadotropin in urine samples from 63 pregnant women was measured with two monoclonal antibodies by immunofiltration technique and 


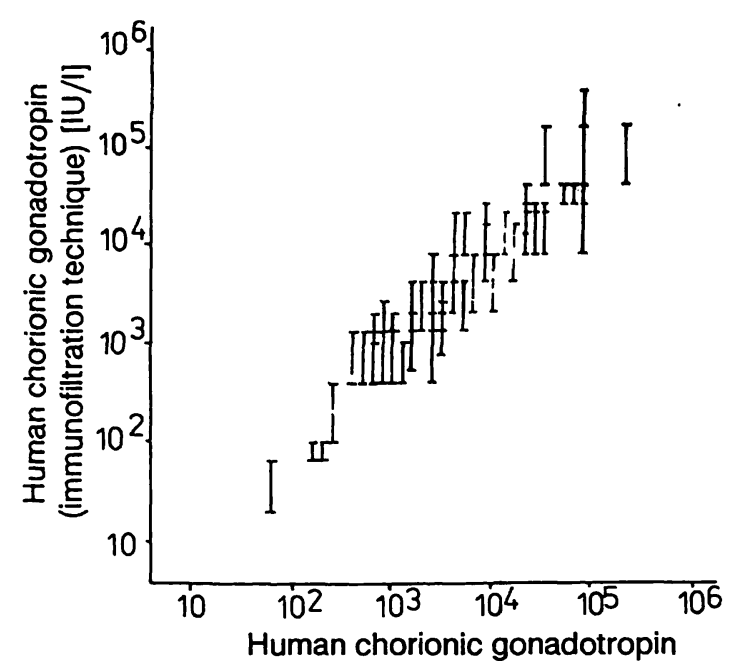

(ELISA) [IU/l]

Fig. 2. Human chorionic gonadotropin in urine of pregnant women was assayed by immunofiltration technique and by ELISA. Two monoclonal antibodies (anti- $\beta$-hCG and anti- $\alpha$ hCG-horse radish peroxidase conjugate) were used in both methods.

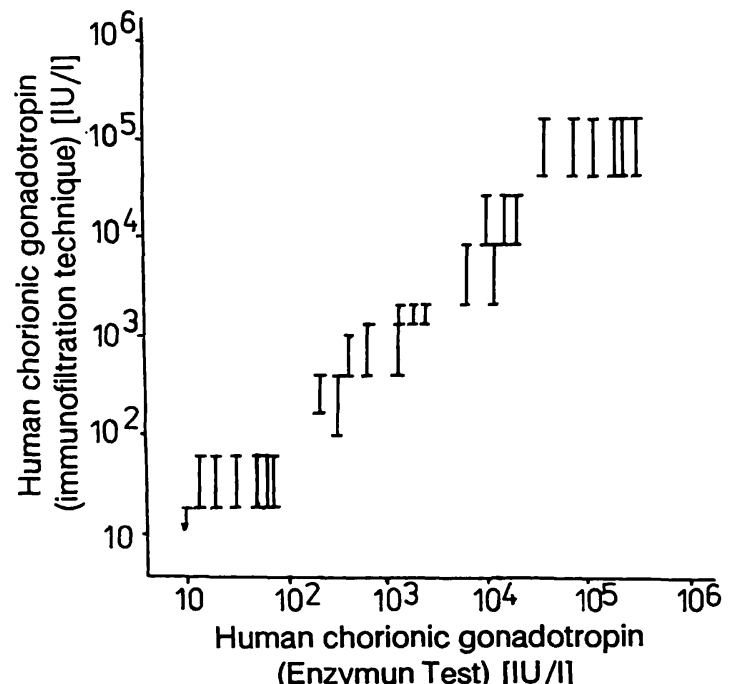

Fig. 3. Human chorionic gonadotropin in sera of patients with trophoblastic diseases assayed by the immunofiltration technique with two monoclonal antibodies, and by the Enzymun Test.

simultaneously by ELISA. The linear correlation between mean values from the immunofiltration technique and from the ELISA (fig. 2) was good $(r=0.87$, $\mathrm{y}=1030+0.98 \mathrm{x})$.

The hormone was also assayed in sera from $27 \mathrm{pa}-$ tients with choriocarcinoma and hydatidiform mole by the immunofiltration technique with monoclonal antibodies, and by the Enzymun Test (fig. 3). The correlation coefficient was $0.86(\mathrm{y}=1.72 \mathrm{x}-796)$.

Immunofiltration technique with polyclonal antibodies

Assays of intact human chorionic gonadotropin by immunofiltration technique with rabbit $\mathrm{Ab}$ anti-122- $145-\beta h C G$ and $\mathrm{Ab}$ anti- $\beta$ hCG-horse radish peroxidase conjugate were almost the same as those with monoclonal antibodies presented in table 3. It was demonstrated also that immun'ofiltration technique with the two polyclonal antibodies was useful for the assay of $\beta h C G$; the ranges of the assays were the same as those for intact human chorionic gonadotropin, but $\alpha \mathrm{hCG}$, human lutropin and human thyrotropin produced a negligible response: $<0.5 \%$. When immunofiltration technique with polyclonal antibodies was used for the assay of human chorionic gonadotropin in sera of 16 patients with trophoblastic diseases (fig. 4), a good correlation was noted between the mean values by immunofiltration technique and the values from the Abbott Test $(r=0.98, y=800$ $+0.89 \mathrm{x})$.

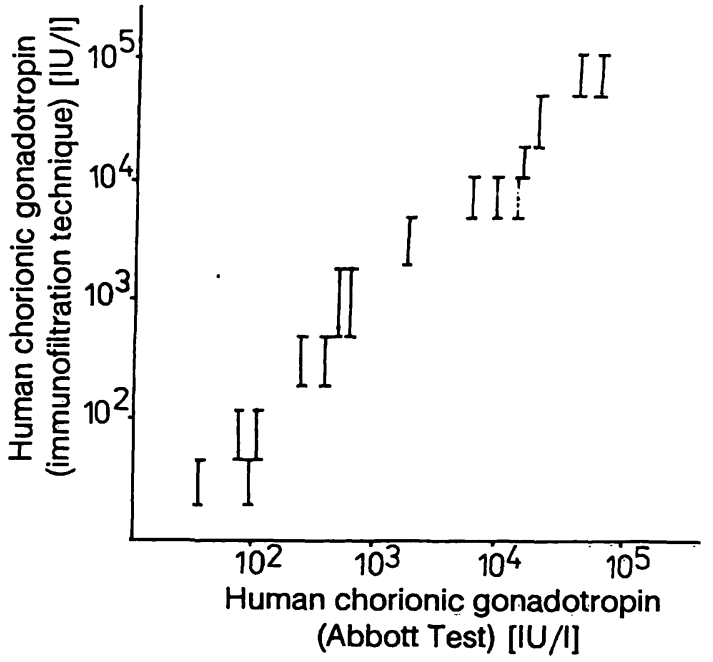

Fig. 4. Human chorionic gonadotropin in sera of patients assayed by the immunofiltration technique with two polyclonal antibodies (anti-122-145- $\beta$ hCG and anti$\beta$ hCG-horse radish peroxidase conjugate), and by the Abbott Test.

\section{Interferences}

Human haemoglobin $(0.4 \mathrm{~g} / \mathrm{l})$, urea $(20 \mathrm{~g} / \mathrm{l})$ and drugs $(1 \mathrm{~g} / \mathrm{l})$ like acetylsalicylic acid, ascorbic acid, diclofenac, co-tri-moxozole, cyclophosphamide, furosemide, ibuprofen, metamizole and theophylline did not affect the immunofiltration technique assays, using either two monoclonal, or two polyclonal antibodies.

\section{Discussion}

We exploited the observation that mono- and polyclonal antibodies adsorb sufficiently to glass microfibre sheet for the simple preparation of immunofilters with antibody bars without activation of the sheet and without the use of a coupling reagent. For localization of the antibody-hCG-antibody-peroxidase bars on immunofilters we applied a solution contain- 
ing tetramethylbenzidine and hydrogen peroxide stabilized with isopropanol. Of 6 chromogenic substrates investigated, this was found to be the most sensitive chromogen for peroxidase (17).

The application of sodium fluoride solution was necessary for inhibition of the peroxidase reaction and reduction of the colour background which slowly appears on the immunofilter. It was demonstrated that the technique with two monoclonal antibodies (anti- $\alpha$ and anti- $\beta$ hCG) is useful for the assay of intact human chorionic gonadotropin, and that two rabbit antibodies (anti-122-145- $\beta$ hCG and anti- $\beta$ hCG) can be used both for intact hormone and its $\beta$-chain.

The immunofiltration technique described in this paper is so fast and simple that can be used for semiquantitative assay of human chorionic gonadotropin in about $8 \mathrm{~min}$, not only in hospitals or laboratories of small clinics, but even by unskilled persons at home.

Dry immunofilters in special plastic devices and the four reagent solutions used for the technique are stable for at least 6 months when stored at $2-6^{\circ} \mathrm{C}$.

The described technique appears to be suitable for monitoring pregnancy and some cancer diseases.

\section{Acknowledgement}

These studies were supported by grant CPBR 4.8/1. We would like to thank Dr. J. Steuden for supplying mouse ascites fluids with monoclonal antibodies. We also wish to thank Dr. $E$. Dobroszycka from 40-Anniversary Hospital for supplying urine samples of pregnant women. Sera of women with trophoblastic diseases were provided by coworkers of Professor $\mathrm{M}$. $\mathrm{Wa}$ wrzkiewicz from the Medical Academy in Wroclaw.

\section{References}

1. Sheehan, C. (1983) Current status of pregnancy testing. Am. J. Med. Technol. 49, 485-488.

2. Talwar, G. P. \& Gaur, A. (1986) Human chorionic gonadotropin, hCG. In: Methods of Enzymatic Analysis, vol. 9 (Bergmeyer, H. U., ed.) pp. 419-439, Weinheim: VCH Verlagsgesellschaft $\mathrm{mbH}$.

3. Morris, D. L., Ledden, D. J. \& Bogulski, R. C. (1987) Dryphase technology for immunoassay. J. Clin. Lab. Anal. 1 , $243-249$.

4. Norman, R. J., Lowings, C. \& Chart, T. (1985) Dipstick method for human chorionic gonadotropin suitable for emergency use on whole blood and other fluids. Lancet $I, 19-20$.

5. Valkirs, G. E. \& Barton, R. (1985) Immunoconcentration - a new format for solid-phase immunoassay. Clin. Chem. $31,1427-1431$.

6. Norman, R. J., Gilmore, T. A. \& McLoughin, J. W. (1992) Simple quantitative measurement of serum choriogonadotropin compared with immunoradiometric, immunoenzymatic and chemiluminescent assays. Clin. Chem. 38, 144147.

7. Osikowicz, G., Beggs, M., Brookhart, P., Caplan, D., Ching, S., Eck, P., Gordon, J., Richerson, R., Sampedro, S., Stimpson, D. \& Walsworth, F. (1990) One-step chromatographic immunoassay for qualitative determination of hCG in urine. Clin. Chem. 36, 1586.

8. Litman, D. J. (1985) Test strip enzyme immunoassay. In: Enzyme Mediated Immunoassay (Ngo, T. T. \& Lenhoff, $\mathrm{H}$. M., eds.) pp. 155-190, New York: Plenum Press.

9. Rugg, J. A., Rigl, Ch. T. \& Leung, K. (1986) Radial partition immunoassay applied to automated quantification of human chorionic gonadotropin with use of two monoclonal antibodies. Clin. Chem. 32, 1844-1848.

10. Morgan, F. J., Canfield, R. E., Vaitukaitis, J. \& Ross, G. T. (1974) Properties of the subunit of human chorionic gonadotropin. Endocrinology 94, 1601-1604.

11. Köhler, G. \& Milstein, C. (1975) Continuous cultures of fused cells secreting antibody of predefined specificity. Nature 256, 495-497.

12. Ey, P. L., Prowse, S. J. \& Jenkin, G. R. (1978) Isolation of pure $\operatorname{IgG}_{1}, \operatorname{IgG}_{2 \mathrm{a}}$ and $\mathrm{IgG}_{2 \mathrm{~b}}$ immunoglobulins from mouse serum using protein A-Sepharose. Immunochemistry 15, $429-436$.

13. Rapak, A. (1990) Immunoenzymatic tests for detection and determination of some proteins in human urine. Institute of Immunology and Experimental Therapy, Wroclaw, Doctoral Thesis.

14. Kochanowska, I. E., Rapak, A., Maćkiewicz, Z., Kupryszewski, G. \& Szewczuk, A. (1991) Goat antibodies to amino acid sequences of human chorionic gonadotropin (hCG). Arch. Immunol. Exp. Ther. 39, 3-10.

15. Wilson, M. B. \& Nakane, P. K. (1978) Recent developments in the periodate method of conjugating horseradish peroxidase conjugate (HRPO) to antibodies. In: Inmunofluorescence and Related Staining Techniques (Knapp, W., Holubar, K. \& Wick, G., eds.) pp. 215-224, Elscvier NorthHolland Biochemical Press, Amsterdam, New York.

16. Greenwood, F. C. \& Hunter, W. M. (1963) The preparation ${ }^{131}$ I-labelled human growth hormone of high specific radioactivity. Biochem. J. 89, 114-119.

17. Rapak, A. \& Szewczuk, A. (1991) Detection and assay of some human proteins by immunoconcentration technique. Arch. Immunol. Ther. Exp. 39, 329-333.

Prof. Dr. Apolinary Szewczuk

Biochemical Laboratory

Institute of Immunology

and Experimental Therapy

Polish Academy of Sciences

ul. Czerska 12

PL-53-114 Wroclaw

Poland

Eur. J. Clin. Chem. Clin. Biochem. / Vol. 31, 1993 / No. 3 
